\title{
Teachers' Views Regarding Workaholism and Occupational Professionalism*
}

\author{
Şenay Sezgin Nartgun ${ }^{1, *}$, Serkan Ekinci ${ }^{2}$, Hayrettin Tukel ${ }^{3}$, İbrahim Limon ${ }^{2}$ \\ ${ }^{1}$ Department of Educational Sciences, Faculty of Education, Abant Izzet Baysal University, Turkey \\ ${ }^{2}$ Institute of Educational Sciences, Abant Izzet Baysal University, Turkey \\ ${ }^{3}$ Ministry of National Education, Turkey
}

Copyright $(\mathrm{C} 2016$ by authors, all rights reserved. Authors agree that this article remains permanently open access under the terms of the Creative Commons Attribution License 4.0 International License

\begin{abstract}
While educational organizations are in the pursuit of survival, they also feel existing and increasing public and environmental pressures. To overcome these pressures requires employees who can respond to these pressures. This also leads the employees to work harder and necessitates them to be more enduring and responsive. If such teachers are working in schools where occupational professionalism is high, they respect to the expertise of their colleagues, work in cooperation, strive for effective teaching and are quite eager to do their job [42]. To have morally sound generations is possible with teachers carrying out their occupations professionally, as well [27]. For these reasons, teachers' being professional may result in workaholism. Workaholics feel obliged to work, not because of external demands or pleasure in work, but because of inner pressures that make the person distressed and guilty about not working [38]. In this respect, the aim of this study is to determine the relationship between teachers' opinions about workaholism and occupational professionalism. The population of the study conducted in relational screening model consists of 218 high school teachers who work in Nevşehir province during the education year of 2015-2016. Workaholism and Occupational Professionalism scales were used as data collection tools. Means and standard deviations were calculated and correlation analysis was conducted to analyze the data. The findings indicate that teachers' opinions about occupational professionalism are "Agree". While the scores for the subscales of 'professional awareness' and 'emotional labor' are the highest, the scores for the sub dimension of 'personal development' and 'contribution to organization' are the lowest. On the other hand, the average score for workaholism and its sub dimension are 'Agree'. This means that teachers perceive themselves as being workaholics.
\end{abstract}

Keywords Professionalism, Workaholism, Teacher, School

\section{Introduction}

Changing world and social pressures are altering and complicating the structure of educational organizations. Staff quality is the most important demand in educational institutions that strive to survive in this complexity. Efforts to meet this demand have oriented the staff to work harder and obliged them to be stronger and more sensitive. These efforts are sometimes defined with the concept of workaholism.

\subsection{Workaholism}

Workaholism, a common concept used to define work addiction [28], refers to individuals who do not feel discomfort from working voluntarily for long periods of time. [17] Compared with the other staff, workaholics have higher work engagement, feel compelled or driven to work because of inner pressures and are low in enjoyment at work [38], they work harder than their job definition requires and exert more efforts in comparison to what is expected from them by their coworkers or managers[34]. Not only strong motivational impulses but also contextual factors such as financial problems, a marriage life that is not going well, organizational culture or a strong desire to build a career are found at the basis of these efforts [40]. In other words, workaholics are tirelessly and relentlessly involved in work related thoughts at every moment of daily life and work excessively by displaying behaviors beyond organizational or economic expectations[39]; [35]. In short, workaholic staff always thinks about work related issues and behaves with an extreme sense of responsibility.

Workaholics experience excessive stress and their work may cause physical and mental problems [21]. Studies on workaholism have found negative outcomes showing that interpersonal relationships of workaholics weaken in terms of quality; workaholics experience work-family conflicts; workaholism negatively affects their well-being and causes burnout and in general has negative outcomes such as low performance, sleep disorders, psychosomatic symptoms and 
low job satisfaction in addition to positive outcomes such as higher work enjoyment compared to others and satisfaction from leading a multifaceted life [39]; [5]. Taking holistically, workaholism is reflected the behaviours, thoughts and experiences of the individual [37]. Workaholics can be differentiated from hardworking staff in terms of their obsession with performance, their tendency to exaggerate and continuous orientation towards bigger goals [36]. Hence, workaholism is defined as the need for perpetual work and excessive work driven by emotions[34].

\subsection{Occupational Professionalism}

While occupation is defined in daily language as the non-voluntary activity for which individuals are paid for [27], professionalism includes the knowledge, skills and behaviors that are believed to be necessary for a professional to display [12]. Professional teacher behaviors involve the seriousness and dignity towards work in addition to commitment among teachers and towards the students [29]. In other words, occupational professionalism of teachers includes perceptions to take their profession seriously, high commitment and going beyond basic expectations in meeting student needs [42].

Teachers perceive occupational professionalism in the context of professional knowledge, skills, attitudes and behaviors [27] and they cite the personal characteristics of professional teachers as the qualities that modern and well-informed individuals have such as being insightful, having the ability to empathize and value others, having self-confidence, ability to self-criticize, openness towards criticism and change [44]. In addition to these qualities, one of the most important prerequisites for being a professional is enhancing the quality of work [2]. Professional conduct cannot only be explained with seniority since the teachers who are just starting their professions with the desired qualities albeit lack of experience may be able to professionally conduct their professions and even display equal or higher level of professionalism compared to experienced teachers [41].

\subsection{The Relationship between Workaholism and Occupational Professionalism}

Teachers respect their coworkers' expertise and competence, work in cooperation, exert efforts to practice effective teaching activities and display higher level of willingness to do their jobs at schools in which occupational professionalism level is high [42]. Educating the future generations as ethically strong individuals will be possible with the existence of teachers who conduct their occupations in the educational system in a professional manner [27]. In this critical point, workaholics feel the pressure to work based on internal pressures that make them feel distressed or guilty rather than external demands or feelings of job satisfaction [38]. Since workaholics have the tendency to practice their professions in the best manner, they attribute importance to professional development.
Although it is known that teachers who participate in professional development activities have higher occupational professionalism perceptions [41], it is found that teachers do not perceive themselves as professional and they generally adopt the idea that professionalism develops in time $[44[$. However, due to the limitations based on the number and impact of civil teaching organizations in Turkey, all decisions and practices related to teaching profession are managed and supervised through a central process and therefore teachers are regarded as practicing operators rather than the members of a professional occupation [18]. Researchers also regard the lack of in-service training opportunities for teachers as a barrier to become professional teachers [44].

\section{Purpose of the Study}

This study aimed to determine the relationship between Nevşehir central district high school teachers' views related to workaholism and occupational professionalism and identify the relationship between these views. In this context, the study sought answers to the following questions:

1. What are the teachers' view related to workaholism and occupational professionalism?

2. Do teachers' view on workaholism and occupational professionalism present significant differences based on demographic characteristics (gender and professional seniority)?

3. Is there a significant relationship between teachers' views on workaholism and occupational professionalism?

\section{Method}

\subsection{Research Model}

This study utilized relational screening model. Relational screening model is a research model that aims to identify the existence and/or degree of simultaneous change between two or more variables [23].

\subsection{Universe}

The universe of the study was composed of 599 teachers employed in Nevşehir central district high schools. Scales were delivered to all teachers employed in central district high schools, however, only 281 teachers who participated in the study voluntarily returned utilizable scales. $20,3 \%$ of the participating teachers had 1-10 years experience, $49,5 \%$ had 11-20 years experience and 30,2\% had 21 years or more experience; $90,4 \%$ had undergraduate degrees and $9.6 \%$ had graduate degrees; $44,1 \%$ were female an $55,9 \%$ were male.

\subsection{Data Collection Tools}

Workaholism and Occupational Professionalism Scales were used in the study as data collection tools. Teachers' 
Occupational Professionalism Scale, developed by Altınkurt and Y1lmaz [4], includes a total of 24 items with Personal Development, Contribution to Organization, Professional Awareness and Emotional Labor sub dimensions and the Cronbach's Alpha coefficient of the scale was found to be .90 [4]. The reliability analysis conducted in the present study found the Cronbach Alpha estimations for "Personal Development, Contribution to Organization, Professional Awareness and Emotional Labor" sub dimensions and for the total scale respectively as $.74 ; .83 ; .69 ; .85$ and .90 . The 5 -point Likert type scale ranges from "Strongly Disagree" to "Strongly Agree".

The Workaholism Battery was developed by Spence and Robbins [38] and adapted to Turkish culture by Ersoy-Kart [16]. The scale is used for various occupations. The Workaholism Battery includes a total of 20 items (18 positive, 2 negative) with two sub dimensions: Work Enjoyment and Drive. There are 9 items in Work Enjoyment dimension and 11 items in Drive sub dimension. The scale is a 5-point Likert type scale ranging from "Strongly Agree" to "Strongly Disagree". Cronbach Alpha internal consistency coefficient for the general scale was found to be $\alpha=.83$ in the adaptation study [16]. Cronbach Alfa internal consistency coefficient for Work Enjoyment, Drive and general scale were respectively $.77, .79$ and .83 in the current study.

\subsection{Data Analysis}

Before the analysis and interpretations, data distribution was examined with Kolmogorov-Smirnov test and it was found that data didn't display normal distribution. Therefore, non-parametric tests were utilized in the study. In this context, means and standard deviations were used to identify teachers' view; Mann Whitney U test and Kruskal Wallis H were used for personal variables and Spearman's Rho correlation analysis was conducted to determine the relationship between workaholism and occupational professionalism. In the study, statistical significance level was accepted as 0.05 .

\section{Findings}

Teachers' view on Workaholism and Occupational Professionalism Scales.

According to Table 1, teachers' occupational professionalism sub dimensions and general scores are as follows: Personal Development $\bar{X}=3,52$; Contribution to Organization $\bar{X}=3,56$; Professional Awareness $\bar{X}=4,36$; Emotional Labor $\bar{X}=4,31$ and total $\bar{X}=3,90$. These findings show that teachers "agree" to occupational professionalism views presented in the scale. In this context, the highest level professionalism was found in Professional
Awareness dimension followed by Emotional Labor and the lowest level professionalism was observed in Personal Development and Contribution to Organization dimensions.

Table 1. Descriptive Statistics for Workaholism and Occupational Professionalism Scales

\begin{tabular}{|c|c|c|c|c|}
\hline \multicolumn{2}{|c|}{ Scales and Sub Dimensions } & $\mathrm{N}$ & $\overline{\mathrm{X}}$ & SS \\
\hline \multirow{5}{*}{$\begin{array}{c}\text { Occupational } \\
\text { Professionalism }\end{array}$} & $\begin{array}{c}\text { Personal } \\
\text { Development }\end{array}$ & 281 & 3,52 & ,67 \\
\hline & $\begin{array}{l}\text { Contribution to } \\
\text { Organization }\end{array}$ & 281 & 3,56 & ,63 \\
\hline & $\begin{array}{c}\text { Professional } \\
\text { Awareness }\end{array}$ & 281 & 4,36 &, 55 \\
\hline & Emotional Labor & 281 & 4,31 &, 55 \\
\hline & Total & 281 & 3,90 & ,47 \\
\hline \multirow{3}{*}{ Workaholism } & Work Enjoyment & 281 & 3,75 & ,61 \\
\hline & Drive & 281 & 3,49 &, 59 \\
\hline & Total & 281 & 3,61 &, 50 \\
\hline
\end{tabular}

Examination of teachers' workaholism sub dimensions and general scores provide the following respective values for Work Enjoyment and Drive: $\bar{X}=3,75 ; 3,49$. General scores related to workaholism presented the value of $\bar{X}=3$, 61 and pointed to "agreement" which shows that teachers' view on Workaholism Scale in general and its sub dimensions were similar and the score ranges pointed to the fact that teachers could be regarded as workhaholics.

\subsection{Findings Obtained from Workaholism and Occupational Professionalism Scales Based on Demographic Variables}

\subsubsection{Gender Variable}

According to Table 2, there were no significant differences based on gender in Occupational professionalism sub dimensions of Personal Development and Contribution to Organization ( $\mathrm{U}=9292 ; 8545, \mathrm{p}>.05)$ while significant differences were found in Professional Awareness and Emotional Labor sub dimensions based on gender $(\mathrm{U}=7833$; $8085, \mathrm{p}<.05)$. Mean ranks pointed to higher professionalism in female teachers in Professional Awareness and Emotional Labor sub dimensions. Examination of the general total indicated no significant differences in terms of gender as was the case in the general scale, Personal Development and Contribution to Organization sub dimensions ( $U=9261,5$, $\mathrm{p}>.05$ ).

No significant differences were found in teacher scores Workaholism Battery in general and Work Enjoyment and Drive sub dimensions based on gender ( $U=9485,5$; 9473; $9296,5, \mathrm{p}>.05$ ). It is observed that female and male teachers have similar perceptions in terms of workaholism. 
Table 2. Mann Whitney U Test Results for Workaholism Scale and Occupational Professionalism Scale Scores Based on Gender

\begin{tabular}{|c|c|c|c|c|c|c|c|}
\hline & Sub Dimension & Gender & $\mathrm{N}$ & Mean Rank & Rank Sum & $\mathrm{U}$ & $\mathrm{p}$ \\
\hline \multirow{10}{*}{$\begin{array}{c}\text { Occupational } \\
\text { professionalism Scale }\end{array}$} & \multirow{2}{*}{ Personal Development } & Female & 124 & 144,56 & 17926 & 9292 & 0,51 \\
\hline & & Male & 157 & 138,18 & 21664 & & \\
\hline & \multirow{2}{*}{$\begin{array}{l}\text { Contribution to } \\
\text { Organization }\end{array}$} & Female & 124 & 131,41 & 16295 & 8545 & 0,07 \\
\hline & & Male & 157 & 148,57 & 23326 & & \\
\hline & \multirow{2}{*}{ Professional Awareness } & Female & 124 & 156,33 & 19385 & 7833 & $0,00^{*}$ \\
\hline & & Male & 157 & 128,89 & 20236 & & \\
\hline & \multirow{2}{*}{ Emotional Labor } & Female & 124 & 154,31 & 19133 & 8085 & $0,01 *$ \\
\hline & & Male & 157 & 130,52 & 20488 & & \\
\hline & \multirow{2}{*}{ Total } & Female & 124 & 144,81 & 17956,5 & 9261,5 & 0,48 \\
\hline & & Male & 157 & 137,99 & 21664,5 & & \\
\hline \multirow{6}{*}{$\begin{array}{l}\text { Workaholism } \\
\text { Battery }\end{array}$} & \multirow{2}{*}{ Work Enjoyment } & Female & 124 & 138,90 & 17223 & 9473 & 0,69 \\
\hline & & Male & 157 & 142,66 & 22398 & & \\
\hline & \multirow{2}{*}{ Drive } & Female & 124 & 144,53 & 17921,5 & 9296,5 & 0,51 \\
\hline & & Male & 157 & 138,21 & 21699,5 & & \\
\hline & \multirow{2}{*}{ Total } & Female & 124 & 143 & 17732,5 & 9485,5 & 0,71 \\
\hline & & Male & 157 & 139,42 & 21888,5 & & \\
\hline
\end{tabular}

$* \mathrm{p}<.05$

\subsubsection{Seniority Variable}

Table 3 presents no significant differences in Occupational Professionalism Scale in general or in its sub dimensions (respectively $\chi_{(2)}^{2}=0,622 ; 4,82 ; 0,328 ; 2,225 ; 0,498, \mathrm{p}>.05$ ) and in Workaholism Scale general or in its sub dimensions $\left(\chi_{(2)}^{2}=0,507 ; 1,171 ; 0,185, \mathrm{p}>.05\right)$ based on seniority. These findings show that teachers with $1-10$ years, $11-20$ years and 21 years and higher seniority had similar views regarding occupational professionalism and workaholism.

Table 3. Kruskal Wallis H Test Results for Workaholism Scale and Occupational Professionalism Scale Scores Based on Seniority

\begin{tabular}{|c|c|c|c|c|c|c|c|}
\hline & Sub Dimension & Seniority & $\mathrm{N}$ & Mean Rank & $\mathrm{Sd}$ & $\mathrm{X}^{2}$ & $\mathrm{p}$ \\
\hline \multirow{15}{*}{$\begin{array}{l}\text { Occupational } \\
\text { professionalism } \\
\text { Scale }\end{array}$} & \multirow{3}{*}{ Personal Development } & $1-10$ years & 57 & 141,11 & \multirow{3}{*}{2} & \multirow{3}{*}{4,82} & \multirow{3}{*}{0,09} \\
\hline & & $11-20$ years & 139 & 150,25 & & & \\
\hline & & 21 years and higher & 85 & 125,81 & & & \\
\hline & \multirow{3}{*}{$\begin{array}{l}\text { Contribution to } \\
\text { Organization }\end{array}$} & $1-10$ years & 57 & 137,53 & \multirow{3}{*}{2} & \multirow{3}{*}{0,328} & \multirow{3}{*}{0,85} \\
\hline & & $11-20$ years & 139 & 143,76 & & & \\
\hline & & 21 years and higher & 85 & 138,81 & & & \\
\hline & \multirow{3}{*}{ Professional Awareness } & $1-10$ years & 57 & 154,99 & \multirow{3}{*}{2} & \multirow{3}{*}{2,225} & \multirow{3}{*}{0,33} \\
\hline & & $11-20$ years & 139 & 136,42 & & & \\
\hline & & 21 years and higher & 85 & 139,11 & & & \\
\hline & \multirow{4}{*}{ Emotional Labor } & $1-10$ years & 57 & 136,06 & \multirow{3}{*}{2} & \multirow{3}{*}{0,498} & \multirow{3}{*}{0,78} \\
\hline & & $11-20$ years & 139 & 140,23 & & & \\
\hline & & 21 years and higher & 85 & 145,56 & & & \\
\hline & & $1-10$ years & 57 & 139,47 & \multirow{3}{*}{2} & \multirow{3}{*}{0,622} & \multirow{3}{*}{0,73} \\
\hline & \multirow[t]{2}{*}{ Total } & $11-20$ years & 139 & 144,66 & & & \\
\hline & & 21 years and higher & 85 & 136,02 & & & \\
\hline \multirow{9}{*}{$\begin{array}{c}\text { Workaholism } \\
\text { Battery }\end{array}$} & \multirow{3}{*}{ Work Enjoyment } & $1-10$ years & 57 & 151,23 & \multirow{3}{*}{2} & \multirow{3}{*}{1,171} & \multirow{3}{*}{0,56} \\
\hline & & $11-20$ years & 139 & 137,62 & & & \\
\hline & & 21 years and higher & 85 & 139,68 & & & \\
\hline & \multirow{3}{*}{ Drive } & $1-10$ years & 57 & 137,62 & \multirow{3}{*}{2} & \multirow{3}{*}{0,185} & \multirow{3}{*}{0,91} \\
\hline & & $11-20$ years & 139 & 142,91 & & & \\
\hline & & 21 years and higher & 85 & 140,15 & & & \\
\hline & \multirow{3}{*}{ Total } & $1-10$ years & 57 & 146,99 & \multirow{3}{*}{2} & \multirow{3}{*}{0,507} & \\
\hline & & $11-20$ years & 139 & 140,93 & & & 0,78 \\
\hline & & 21 years and higher & 85 & 137,09 & & & \\
\hline
\end{tabular}

\footnotetext{
$* \mathrm{p}<.05$
} 
Table 4. Correlation Analysis (Spearman's Rho) for the Relationship between Teachers Views on Workaholism and Occupational Professionalism

\begin{tabular}{|c|c|c|c|c|c|c|}
\hline & & $\begin{array}{c}\text { Occupational } \\
\text { professionalism }\end{array}$ & $\begin{array}{c}\text { Personal } \\
\text { Development }\end{array}$ & $\begin{array}{c}\text { Contribution to } \\
\text { Organization } \\
\end{array}$ & $\begin{array}{c}\text { Professional } \\
\text { Awareness } \\
\end{array}$ & $\begin{array}{c}\text { Emotional } \\
\text { Labor }\end{array}$ \\
\hline Workaholism & $\mathrm{r}$ & $0,58 * *$ & $0,44 * *$ & $0,53 * *$ & $0,36^{* *}$ & $0,43 * *$ \\
\hline Work Enjoyment & $\mathrm{r}$ & $0,47 * *$ & $0,33 * *$ & $0,37 * *$ & $0,33 * *$ & $0,39 * *$ \\
\hline Drive & $\mathrm{r}$ & $0,52 * *$ & $0,41 * *$ & $0,51 * *$ & $0,28 * *$ & $0,34 * *$ \\
\hline
\end{tabular}

\subsection{The Relationship between Workaholism and Occupational Professionalism}

Table 4 presents a positive medium level significant relationship between workaholism and occupational professionalism in general $(\mathrm{r}=, 58 ; \mathrm{p}<.05)$; Personal Development $(\mathrm{r}=, 44 ; \mathrm{p}<.05$; Contribution to Organization sub dimensions $(\mathrm{r}=, 53 ; \mathrm{p}<.05)$ and Professional Awareness $(\mathrm{r}=, 36 ; \mathrm{p}<.05)$ and Emotional Labor sub dimensions $(\mathrm{r}=, 43$; $\mathrm{p}<.05)$.

On the other hand, a positive medium level significant relationship was found between Work Enjoyment sub dimension and Occupational Professionalism in general $(\mathrm{r}=, 47 ; \mathrm{p}<.05)$, and between Work Enjoyment and other sub dimensions of occupational professionalism (Personal Development $(\mathrm{r}=, 33 ; \mathrm{p}<.05)$, Contribution to Organization $(\mathrm{r}=, 37 ; \mathrm{p}<.05)$, Professional Awareness $(\mathrm{r}=, 33 ; \mathrm{p}<.05)$ Emotional Labor $(r=, 39 ; \mathrm{p}<.05)$.

A positive medium level significant relationship was found between Drive sub dimension and Occupational Professionalism in general $(\mathrm{r}=, 52 ; \mathrm{p}<.05)$ and with Personal Development $(\mathrm{r}=, 41 ; \mathrm{p}<.05)$, Contribution to Organization $(\mathrm{r}=, 22 ; \mathrm{p}<.05)$ and Emotional Labor $(\mathrm{r}=, 34 ; \mathrm{p}<.05)$, however, according to Table 4 , there was a low level positive and significant relationship between Drive and Professional Awareness $(\mathrm{r}=, 28 ; \mathrm{p}<.05)$.

\section{Discussion, Result and Suggestions}

This study conducted to determine teachers' view on workaholism and occupational professionalism presented that teachers "agreed" to views regarding workaholism and occupational professionalism. In this context, it was found that the highest level professionalism was presented in Professional Awareness and Emotional Labor sub dimensions, followed by Emotional Labor while the lowest level of professionalism was found in Personal Development and Contribution to Organization sub dimensions. Based on the results of studies conducted to assess occupational professionalism in general, Koşar, Kılınç, Er, Öğdem and Savaş [26], Altınkurt and Yılmaz [4], Kılınç [25] and Çelik,[14] found teachers to be professionals at medium level while Bayhan [8] Cerit[11], Pearson and Moomaw [33], Tukonic and Harwood [43] and Çekin [13] and Karaca, [22] reported that teachers were high level professionals. It can be argued that teachers perceive themselves as professionals who work in cooperation and communicate well with their coworkers; are aware of their professional needs, are open to new ideas and change, strive to conduct their professions in the best manner and display model behaviors to their students and as a requirement and nature for professionalism, they manage emotions according to organizational and professional needs regardless of their emotional states and do not reflect them on the teaching process and can display agreeable behaviors in their work environments.

Teachers who perceive themselves as professionals also regard themselves as workaholics. This is partly related to the fact that teaching profession is a job of passion and teachers who want to lead their students to success tend to work harder. Özdemir's [32] study found that teachers' workaholism tendencies were higher in general and in sub dimensions.

While there were no significant gender-related differences in teachers' view in Personal Development and Contribution to Organization sub dimensions of Occupational Professionalism; significant differences were observed in Professional Awareness and Emotional Labor sub dimensions based on gender. Female teachers were found to be more professional in Professional Awareness and Emotional Labor sub dimensions. This finding may be related to the fact that teaching is still perceived as an occupation for females.

In general total, the Occupational Professionalism Scale did not generate significant differences based on gender as was the case in Personal Development and Contribution to Organization sub dimensions. This result is similar to the findings of previous studies [4], [8], [14], [22].

Gender variable was not found to create significant differences in teachers' view related to workaholism. This result is similar to the findings obtained in studies conducted by Naktiyok and Karabey [30], Oğuz and Akın [31], Akın and Oğuz [1], Bardakçı and Baloğlu [7]; Argon and Sezgin-Nartgün [6], Altun-Dilek, and Yllmaz [3] and Yüksekbilgili and Akduman [45]. On the other hand, some of the studies in the literature [10]; [20]; [9]; [36]; [32]; gender variable was reported as a variable that generated significant differences. Compared to males, females had higher scores in Emotional Labor and Professional Awareness sub dimensions and this finding may be explained with the fact that females have different emotional habit of body compared to men, are more emotional, supportive and open in personal relationships, have a more developed sense of politeness, mercy, responsibility and commitment and care for love and close relationships [15] and that teaching profession is based on human relationships.

Based on seniority, no significant differences were found 
in teachers' view related to occupational professionalism in general and its sub dimensions. This finding showed that teachers with1-10 years, 11-20 years and 21 years or higher seniority had similar views on issues related to occupational professionalism and workaholism [4], [8], [41], [14], [22], [43]. It has been previously reported that professional seniority does not have any statistically significant contribution to professionalism and that the value placed on professional development is a determinant in this sense [41].

No significant differences were observed in workaholism in general and its sub dimensions based on seniority. According to findings obtained in the study, teachers' workaholic tendencies did not differentiate based on seniority and this result is similar to the findings obtained by Altun-Dilek and Yilmaz [3] in their study.

A medium level, positive and significant relationship was found between workaholism in general and occupational professionalism in general and between Personal Development, Contribution to Organization, Professional Awareness and Emotional Labor sub dimensions. On the other hand, a medium level, positive and significant relationship was found between Work Enjoyment sub dimension and occupational professionalism in general and Emotional Labor, Personal Development, Contribution to Organization, Professional Awareness and Emotional Labor sub dimensions. While there was a medium level, positive and significant relationship between Drive sub dimension and occupational professionalism in general, Personal Development and Contribution to Organization and Emotional Labor sub dimensions; a low level positive and significant relationship was detected between Drive sub dimension and Professional Awareness sub dimension.

Based on these findings, it can be argued that teachers whose workaholism levels are high will also have higher levels of occupational professionalism. Workaholic teachers who are committed to their work will struggle to do their best while conducting their professions. It can also be argued that teachers who display the indicators of occupational professionalism such as self-development, openness to innovations, awareness of professional needs, cooperation with internal and external stakeholders, contribution to the development of school environment, awareness of rights and responsibilities, management of emotions according to organizational and professional goals, behaving in accordance with the ethical principles of teaching profession and displaying model behaviors to students will also love their jobs, will enjoy working and therefore exert efforts to increase the quality of their work. In this context, professionalism may increase enjoyment from work and also influence their motivations. Providing increased opportunities for teachers to develop themselves may also enhance their motivation.

\section{Note}

*The abstract of this paper was presented at 2nd
International Conference on Lifelong Learning and Leadership for All (ICLEL-16), in Liepaja on July, 21-23, 2016.

\section{REFERENCES}

[1] Akın, U. \& Oğuz, E. (2010). Öğretmenlerin işkoliklik ve tükenmişlik düzeylerinin ilişkisi ve çeşitli değişkenler açısından incelenmesi. Kuram ve Uygulamada Ĕ̆itim Yönetimi, 16 (3), 309-327.

[2] Altan, M. Z. (2012). Profesyonel Öğretmenliğe Doğru. Ankara: Pegem Akademi.

[3] Altun-Dilek, S. \& Y1lmaz, K. (2015). Öğretmenlerin İşkoliklik Eğilimleri İle İş- Yaşam Dengeleri. Kafkas Ĕgitim Araştırmaları Dergisi, 3(1), 36-55.

[4] Altınkurt, Y. \& Yılmaz, K. (2014). Öğretmenlerin mesleki profesyonelliği ile iş doyumları arasındaki ilişki. Sakarya University Journal of Education, 4(2), 57-71.

[5] Andreassen, C. S. (2014). Workaholism: An overview and current status of the research. Journal of Behavioral Addictions, $3(1), 1-11$.

[6] Argon, T. \& Sezgin-Nartgün, Ş. (2015). Maarif müfettişlerinin işe bağlı gerginlik ve işkoliklik düzeylerine yönelik görüşleri. VII. Uluslararası Eğitim Denetimi Kongresi. Selçuk, İzmir.

[7] Bardakçı, S. \& Baloğlu M. (2012). İlköğretim ve ortaöğretim kurumlarında görev yapan okul yöneticilerinin işkoliklik eğilimleri. Eğitim ve Bilim Dergisi, 37(164), 45- 56.

[8] Bayhan, G. (2011). Öğretmenlerin Profesyonelliğinin İncelenmesi. Yayımlanmamış doktora tezi. Marmara Üniversitesi Eğitim Bilimleri Enstitüsü, İstanbul.

[9] Burke, R.J., Matthiesen, S. B. \& Pallesen, S. (2006). Personality correlates of workaholism. Personality and Individual Differences, 40, 1223-1233.

[10] Burke, R.J. (1999). Workaholism in organizations: Gender differences. Sex Roles, 41, 333-345.

[11]Cerit, Y. (2012). Okulun bürokratik yapısı ile sınıf öğretmenlerinin profesyonel davranışları arasındaki ilişki. Kuram ve Uygulamada Eğitim Yönetimi, 18 (4), 497-521.

[12] Creasy, K.L. (2015). Defining professionalism in teacher education programs. Journal of Education \& Social Policy, 2(2), 23-25.

[13] Çekin A. (2015). İmam-Hatip lisesi meslek dersleri öğretmenlerinin profesyonelliği üzerine bir araştırma International Journal of Social Science, 37, 85-100.

[14] Çelik, M. (2015). Öğretmenlerin mesleki profesyonelliği ile tükenmişlikleri arasındaki ilişki. Yayınlanmamış Yüksek Lisans Tezi. Dumlupınar Üniversitesi, Eğitim Bilimleri Enstitüsü, Kütahya.

[15]Ersoy, E. (2009). Cinsiyet kültürü içerisinde kadın ve erkek kimliği. Fırat Universitesi Sosyal Bilimler Dergisi. 19 (2), 209-230.

[16] Ersoy-Kart, M. (2005). Reliability and validity of the 
Workaholism Battery (Work-Bat): Turkish form. Social Behavior \& Personality, 33(6), 609-618.

[17] Fujimoto, T. (2014). Workaholism and mental and physical health. Japan Labor Review. 11(1), 50-67.

[18] Güven, D. (2010). Profesyonel Bir Meslek Olarak Türkiye'de Öğretmenlik. Boğaziçi Üniversitesi Eğitim Dergisi. 27 (2), 11-25.

[19] Geist, J. \& Hoy, W. K. (2004). Cultivating a culture of trust: Enabling school structure, teacher professionalism, and academic press. Leading and Managing. 10 (1), 1-18.

[20] Harpaz, I., \& Snir, R. (2003). Workaholism. Its definition and nature. Human Relations, 56 (3), 291-319.

[21] Jenaabadi, H., Nejad, B.A., Abadi, F.S.M., Haghi, R. \& Hojatinasab, M. (2016). Relationship of Workaholism with Stress and Job Burnout of Elementary School Teachers. Health, $8,1-8$.

[22] Karaca, D. (2015). İlk ve Ortaokullarda Bürokratikleşme Düzeyinin Öğretmen Profesyonelliğine Etkisi. Yayımlanmamış Doktora Tezi Pamukkale Üniversitesi. Eğitim Bilimleri Enstitüsü. Denizli.

[23] Karasar, N. (2011). Bilimsel Araştırma Yöntemi. Ankara: Nobel yayın dağıtım.

[24] Kılınç, A. Ç., Cemaloğlu, N., \& Savaş, G. (2015). The relationship between teacher leadership, teacher professionalism, and perceived stress. Eurasian Journal of Educational Research, 58, 1-26.

[25] Kılınç, A. Ç. (2014). Öğretmen profesyonelizminin bir yordayıc1sı olarak okul kültürü. Eğitim ve Bilim, 39 (174). 105-118.

[26] Koşar, S., Kılınç, A. Ç., Er, E., Öğdem, Z. \& Savaş, G. (2014). Examining the Relationship between Teachers' Perceptions of Primary School Principals' Power Styles and Teacher Professionalism. Alberta Journal of Educational Research, 60(2), 322-338.

[27] Mabagala, S. (2015). The Perspectives of Physical Education Teachers in Tanzania on Teacher Professionalism. International Journal of Education and Research, 3(10), 13-22.

[28] Matuska, K.M. (2010). Workaholism, Life Balance, and Well-Being: A Comparative Analysis. Journal of occupatıonal sclence. 17 (2), 104-111.

[29] Mitchell, R.M. \& Tarter, J. (2016). A Path Analysis of the Effects of Principal Professional Orientation towards Leadership, Professional Teacher Behavior, and Social Academic Optimism on School Reading Achievement. Societies, 6 (5), 2-11.

[30] Naktiyok, A. \& Karabey, C. N. (2005). İşkoliklik ve tükenmişlik sendromu. Atatürk Üniversitesi İktisadi ve İdari Bilimler Dergisi, 19 (2), 179-198.

[31] Oğuz, E. \& Akın, U. (2008). Öğretmenlerin işkoliklik düzeyleri ile evlilik uyumları arasındaki ilişski. International
Conference on Educational Sciences. Eastern Mediterranean University. Famagusta, North Cyprus. 23-25.

[32] Özdemir, H. (2013). Sınıf Öğretmenlerinin İşkoliklik Eğilimlerinin İncelenmesi. Yayımlanmamış Yüksek Lisans Tezi. Marmara Üniversitesi, Eğitim Bilimleri Enstitüsü, İstanbul.

[33] Pearson, L. C. \& Moomaw, W. (2005). The relationship between teacher autonomy and stress, work satisfaction, empowerment, and professionalism. Educational Research Quarterly, 29 (1), 38-54.

[34] Schaufeli, W. B., Taris, T. W., \& Van Rhenen, W. (2008). Workaholism, burnout, and work engagement: Three of a kind or three different kinds of employee burnout? Applied Psychology: An International Review, 57, 173-203.

[35] Shimazu A \& Schaufeli, W.B. (2009). Is workaholism good or bad for employee well-being? The distinctiveness of workaholism and work engagement among Japanese employees. Ind Health. 47, 495-502.

[36] Smith, A. L. (2011). Gender and Workaholism: A Study of New Zealand Academics. Victoria University of Wellington.

[37] Součková M., Vaculík M. \& Procházka J. (2014). Personality Traits and Workaholism. International Journal of Humanities and Social Science, 4 (14) 70-79.

[38] Spence, J.T. \& Robbins, A.S. (1992). Workaholism: Definition, measurement, and preliminary results. Journal of Personality Assessment, 58(1), 160-78.

[39] Tabassum, A. \& Rahman, T. (2013). Gaining the insight of workaholism, its nature and its outcome: A literature review. International Journal of Research Studies in Psychology. 2(2), 81-92.

[40] Taris, T.W., Schaufeli, W.B. \& Verhoeven, L.C. (2005) Workaholism in the Netherlands: Measurement and Implications for Job Strain and Work-Nonwork Conflict. Applied Psychology: An International Review, 54 (1), 37-60.

[41] Toh, K. A., Diong, C. H., Boo, H. K. \& Chia, S. K. (1996). Determinants of teacher professionalism. British Journal of In-Service Education, 22 (2), 231-244.

[42] Tschannen-Moran, M. (2009). Fostering teacher professionalism in schools; the role of leadership orientation and trust. Educational Administration Quarterly, 45 (2), 217-247.

[43] Tukonic, S \& Harwood, D. (2015). The glass ceiling effect: Mediating influences on early years educators' sense of professionalism. Journal of the Canadian Association for Young Children, 40 (1), 36-54.

[44] Uzun, S., Paliç, G. \& Akdeniz, A.R. (2013). Fen Ve Teknoloji Öğretmenlerinin Profesyonel Öğretmenliğe İlișkin Algiları. Buca Ĕ̈itim Fakültesi Dergisi. 35, 128-145.

[45] Yüksekbilgili Z. \& Akduman G. (2016). Demografik Faktörlere Göre ișkoliklik. Elektronik Sosyal Bilimler Dergisi. 15 (57) 512-525. 